\title{
Project-Based Science to Increase Language Ability in Early Childhood
}

\author{
Christiani Endah Poerwati \\ Early Childhood Teacher Education \\ Universitas Dhyana Pura \\ Bali, Indonesia \\ christianiendah@undhirabali.ac.id
}

\author{
Ni Luh Rimpiati \\ Early Childhood Teacher Education \\ Universitas Dhyana Pura \\ Bali, Indonesia \\ rimpiati@undhirabali.ac.id
}

\begin{abstract}
Indeed early childhood is ready to learn many things including science. Great curiosity in children is a potential that can be exploited to introduce various concepts of science through exploration, observation and experimentation in the context of play. Children love to explore the surroundings with their senses, investigate objects, and make experiments in their daily activities, including playing. Science is a science based on findings through investigations and experiments. So it is possible to introduce science to children through project activities. Project-based science is a very interesting activity for children, because through this activity various abilities of children can be developed including the ability of children's language. Investigation activities develop the child's ability to present ideas, make inquiries, make notes, and propose arguments. Exploration activities develop the child's ability to discover new concepts, new words and new meanings. The experimental activity develops the child's ability to understand the stages of activity and the various rules. Group activities train children to communicate with peers, discuss and present their work.
\end{abstract}

Keywords-project-based science; language ability; early childhood

\section{INTRODUCTION}

The knowledge and technology development is a sign of the era and human civilization progress. Science and mathematics underlies the progress. Mastering science and math is absolutely necessary to build a developed country and able to compete with other countries. Ironically, based on the 2015 TIMSS (Trends in International Mathematics and Science Study), Indonesian students ranked is in $45^{\text {th }}$ out of 48 countries in terms of mathematical achievement and $40^{\text {th }}$ in 42 of the country in science achievements (TIMSS) [1], Generally, many students consider science and math is a difficult subject to be a scourge to learn it. Therefore, science needs to be introduced from an early age with the right method, fun and meaningful way.
Introduce science to early childhood in Permendikbud, No. 137, 2014 [2] set forth in the sphere of cognitive development includes learning and problem solving, logical thinking and symbolic thinking. Teachers can develop through various activities that support child's ability to recognize the various concepts of science. But, in fact the introduction of science in early childhood is limited to general knowledge and concepts and there is no specific activity or learning about science with an approach that allows children to learn and construct their own knowledge. Teachers are too focused on calistung (read, write, count), as parents demand and elementary school preparation. Based on research by Yilmaztekin \& Erden [3], in order to find out 5 early childhood teachers' views about early childhood science, semi-structured interviews and classroom observations were used in this study. The participating early childhood teachers were asked about their views on the implementation of science activities, the usage of science teaching methods in early childhood classrooms, the implementation of science process skills, and scientific concepts. The preliminary findings showed that all of the participant teachers preferred to apply science activities at least once in their weekly plans. Some of them focused on children's interests while some others mentioned the requirement of planning a special day. Furthermore, one participant thought that the attitudes of parents toward this issue was not adequate because most of the parents did not give importance to science when compared to the academic success such as reading, writing, and mathematics.

Indeed, early childhood is ready to learn many things including science. Great curiosity in children can be potentially exploited to introduce various concepts of science through exploration, observation and experimentation in the context of play. Children love to explore the surroundings with their senses, investigate objects and make experiments in their daily activities, including playing. Science is a science based on findings through investigations and experiments. So it is possible to introduce science to children through project activities. 
Project-based science is very interesting activity for children because through this activity various abilities of children can be developed including the ability of children's language. As stated by Pam Scranton, [4]. "I just love to do project with children because I think it is exciting watching them construct own knowlegde base...watching them decide what interest them the most, investigating it, asking questions about it. I like seeing children excited about what they're doing, excited about their learning. I like watching them almost on fire because they can't get the materials in their hands fast enough to represent what they're learning as they investigate a topic. I think it is just the best way for children to grow and for their brains to develop"

The ability of the children's language possible to developed through the project-based science as project activities incorporate various abilities of children in their learning process, including language. Investigation activities develop the child's ability to present ideas, make inquiries, make notes and propose arguments. Exploration activities develop the child's ability to discover new concepts, new words and new meanings. The experimental activity develops the child's ability to understand the stages of activity and the various rules. Group activities train children to communicate with peers, discuss and present their work. Research from Brooks \& Wangmo [5] that the Primary 1 and Primary 2 children of Taju Elementary School and their teachers, the Project Approach provided a supportive framework for introducing new ways of teaching and learning that are more child friendly than traditional methods. Working through the three phases of the Project Approach engaged children and teachers in activities and processes that facilitated their transformative development.

\section{LITERATURE REVIEW}

\section{A. Project Method}

Moeslichatoen [6], stated that the project method is one of learning provision experience by confronting children on daily issues that must be done in groups. Meanwhile Helm \& Katz [4] stated that, A project is an in-depth investigations of a topic worth learning more about. The investigation is usually undertaken by a small group of children within a class, somestimes by a whole class, and occasionally by an individual child. The key feature of a project is that it is a research effort deliberately focused on finding answers to questions about a topic posed either by the children, the teacher, or the working with the children. The project method is derived from John Dewey's idea about "Learning by Doing", which is the process of obtaining learning outcomes by doing certain actions in accordance with its objectives. Especially the process of controlling the child to do a task consisting of a series of behaviors to achieve the goal. Piaget says that we can not teach a child verbally about a concept, but we can teach it when using methods based on child activity (Sava) [6]. Here is a picture of the stages of the project method developed by Helm \& Katz [4].

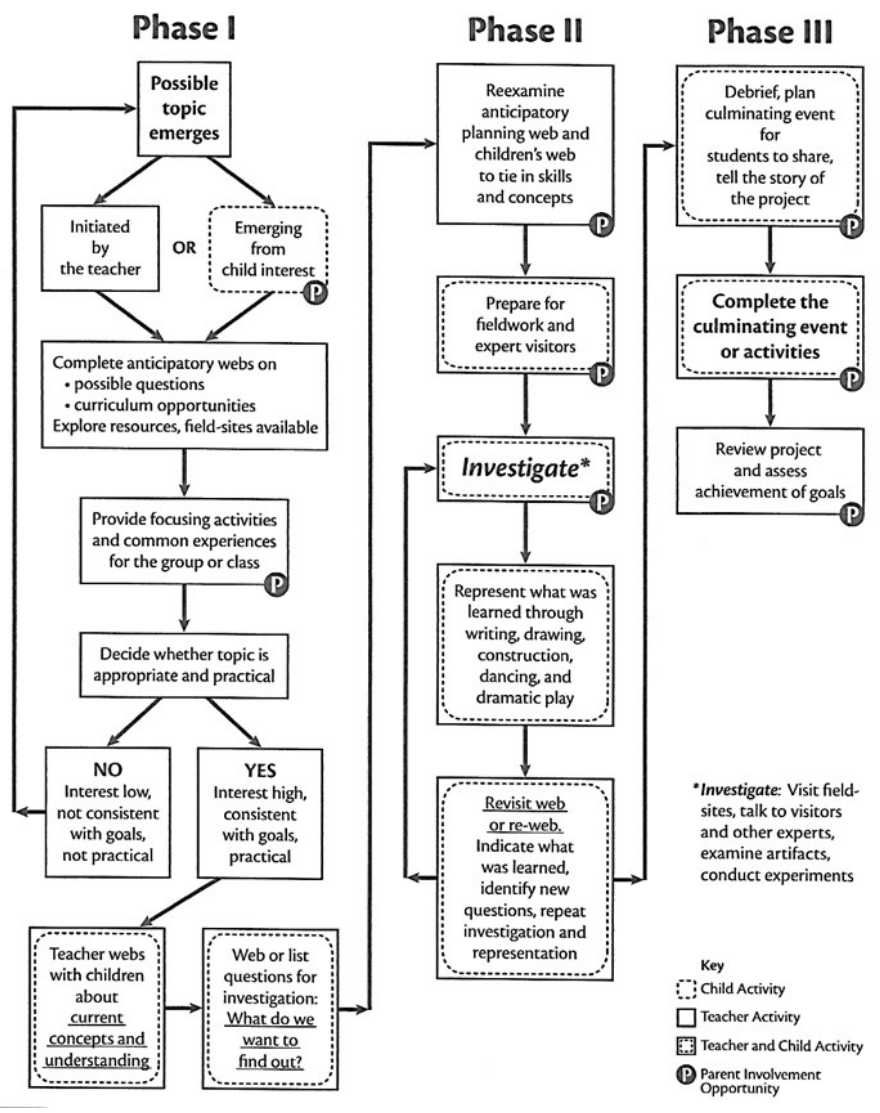

Figure 2.1. Phases of a Project ( Helm \& Katz 2011)

\section{B. Project-based science}

The project method can give children the opportunity to express their mind, skills and abilities to maximize the number of problems for them so that they have the opportunity to be creative and develop themselves optimally [6]. The stage of activities that teachers can prepare in planning project activities, as developed by Lilian G, Katz et.al can be seen in Figure 2.2 below.

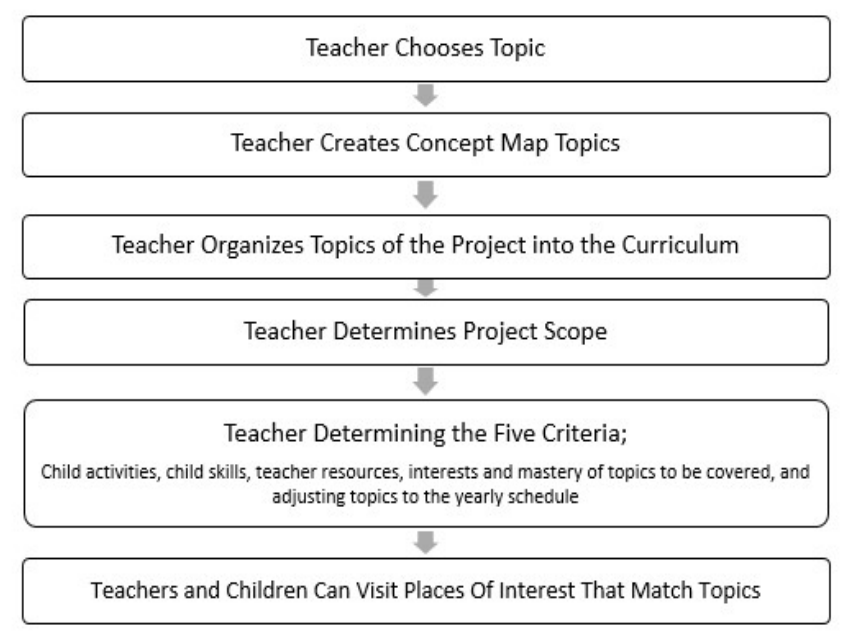

Figure 2.2. Design of Project Activities[6] 
The following can be developed the design of science project activities for early childhood through activities that are simple and appropriate to the age and level of understanding of the child.

Table 2.1. Design of Science Project Activities

\begin{tabular}{|c|c|c|}
\hline \multicolumn{3}{|c|}{$\begin{array}{l}\text { Theme: My body } \\
\text { Time: } 1 \text { week ( } 5 \text { days) } \\
\text { Material: Bone } \\
\text { Project: Eggshell } \\
\text { Tools and materials: plastic cups, vinegar, chicken eggs, salt, } \\
\text { water, Worksheets }\end{array}$} \\
\hline Material & Child Activities & Teacher Activity \\
\hline $\begin{array}{l}\text { Images of } \\
\text { human } \\
\text { skeletons }\end{array}$ & Watching pictures & $\begin{array}{l}\text { Describes pictures } \\
\text { in simple way }\end{array}$ \\
\hline $\begin{array}{l}\text { Tools and } \\
\text { materials }\end{array}$ & $\begin{array}{ll}- & \text { Mentioning tools } \\
\text { and materials } \\
\text { - } & \text { Divided into work } \\
\text { groups }\end{array}$ & $\begin{array}{l}\text { - Explaining tools } \\
\text { and materials } \\
\text { - Shares the tools } \\
\text { and materials of } \\
\text { each group }\end{array}$ \\
\hline $\begin{array}{l}\text { Stages of } \\
\text { project } \\
\text { activities }\end{array}$ & $\begin{array}{ll}\text { - } & \text { Watching the } \\
\text { demonstration } \\
\text { - } \\
\text { Practicing the } \\
\text { stages of activity }\end{array}$ & $\begin{array}{l}\text { - Explaining and } \\
\text { demonstrate the } \\
\text { stages of the } \\
\text { activity }\end{array}$ \\
\hline Worksheet & $\begin{array}{l}\text { Work and save } \\
\text { daily worksheets } \\
\text { in groups based on } \\
\text { observations and } \\
\text { investigations }\end{array}$ & $\begin{array}{l}\text { - Explains how to } \\
\text { work on a } \\
\text { worksheet }\end{array}$ \\
\hline $\begin{array}{l}\text { Observations } \\
\text { and } \\
\text { discussion }\end{array}$ & 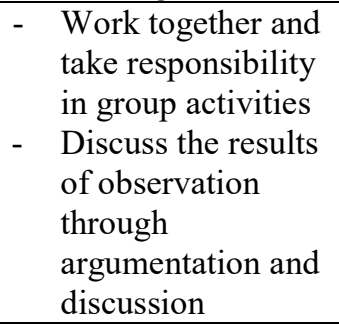 & $\begin{array}{l}\text { - Motivate, } \\
\text { facilitate and } \\
\text { mediate } \\
\text { observation } \\
\text { activities and } \\
\text { discussion of } \\
\text { children in groups }\end{array}$ \\
\hline $\begin{array}{l}\text { Question and } \\
\text { answer }\end{array}$ & $\begin{array}{l}\text { Ask questions and } \\
\text { find answers } \\
\text { through teachers' } \\
\text { observations and } \\
\text { explanations }\end{array}$ & $\begin{array}{l}\text { Motivate and } \\
\text { facilitate the } \\
\text { child to ask } \\
\text { questions } \\
\text { - Answering child } \\
\text { questions } \\
\end{array}$ \\
\hline Presentation & $\begin{array}{ll}\text { - } & \text { Presenting daily } \\
\text { observation results }\end{array}$ & $\begin{array}{ll}\text { - } & \text { Facilitate } \\
\text { presentations and } \\
\text { discussions }\end{array}$ \\
\hline
\end{tabular}

\section{Early Childhood Language Skills}

For children in three, four, and five years old, they on a period of tremendous growth of their language. The vocabulary extends and the semantic structure and syntax of their language becomes increasingly complex. Any changes in terms of this language represented cognitive development. Children becoming a complex thinker and in line with their growth, these changes are reflected in their language. Children in three, four, and five-year-old want to know about the language and increasingly believe in the language to inform their desires and needs [7]. The language phases of children ages 4-6 are described in Table 2.2 below.

Table 2.2. Phase of Children's Language in 4-6 Years Old Using full sentences (about 4-6 years old) 5 to 6 years Complex, correct grammatical sentences, using nouns, using the past, using current time, and verbs in sentence form; The average length of an oral sentence increases to 6.8 words.

Vocabulary: uses about 2,500 words, understands about 6,000, responds 325,000 .

Social: The child has good control of the conversation element

Sources: Jalongo, 2007[8]

Whereas, Level Achievement Standards of Child Development in Group of 5-6 Years Old. Scope of Language Development described in table 2.3 below.

Table 2.3. Language Development Level Achievement of Ages5-6 Years Old [2]

\begin{tabular}{|c|c|}
\hline $\begin{array}{l}\text { Scope of } \\
\text { Developmen } \\
t\end{array}$ & $\begin{array}{l}\text { Level of Achievement of Child Development 5-6 } \\
\text { Years }\end{array}$ \\
\hline $\begin{array}{l}\text { II. Bahasa } \\
\text { II. Language } \\
\text { A.Understan } \\
\text { ding } \\
\text { Language }\end{array}$ & $\begin{array}{l}\text { 1. Understand several commands } \\
\text { simultaneously } \\
\text { 2. Repeating more complex sentences } \\
\text { 3. Understand the rules in a game } \\
\text { 4. Enjoy and appreciate reading }\end{array}$ \\
\hline $\begin{array}{l}\text { B. } \\
\text { Revealing } \\
\text { Language }\end{array}$ & $\begin{array}{l}\text { 1. Answering more complex questions } \\
\text { 2. Mention the group of images that have the } \\
\text { same sound } \\
\text { 3. Communicate orally, have vocabulary, and } \\
\text { recognize the symbols for the preparation of } \\
\text { reading, writing and arithmetic } \\
\text { 4. Compose simple sentences in the complete } \\
\text { structure (the subject of sentence-predicate) } \\
\text { 5. Learn more words to express ideas to others } \\
\text { 6. Continuing some stories / tales that have } \\
\text { been played } \\
\text { 7. Demonstrate an understanding concepts in } \\
\text { storybooks }\end{array}$ \\
\hline C. Literacy & $\begin{array}{l}\text { 1. Mention the familiar letter symbols } \\
\text { 2. Recognizing the sound of the initial letter of } \\
\text { the name of objects } \\
\text { 3. Mention groups of images that have the same } \\
\text { initial sound / letter } \\
\text { 4. Understand the relationship between sound } \\
\text { and letter form } \\
\text { 5. Read your own name } \\
\text { 6. Write their own name } \\
\text { 7. Understand the meaning of the word in the } \\
\text { story }\end{array}$ \\
\hline
\end{tabular}




\section{Methods of Project and Development Early Childhood Language Skills}

The prekindergarten, kindergarten, and first-grade years are recognized as key years for the development of communicative competence, including language and understanding of symbol systems. While in the past teachers were sometimes discouraged from introducing reading and paper-and-pencil activities into the prekindergarten, teachers are now strongly encouraged to a provide a literacy-rich environment in kindergarten as well as preschool classes. Although whole-group, formal instruction in reading and writing is still difficult for children from 3 to 5 years of age, they begin to represent concepts and ideas through drawing and early writing.

Young investigators are often highly motivated to show others what they have learned about a topic. Young investigators create play environments, block structures, buildings, and other products related to the project. Often children want to show what they know about a topic by writing about it. As children build block structures related to a topic (e.g., a barn, during an investigation of a local farm), they often write signs to identify the parts of their structure (e.g., hay loft). When they make a dramatic play environment such as a restaurant, they may create signs or other literacy items to make their play environment more realistic (e.g., menus or notices of opening hours) [4].

\section{CONCLUSION}

Indeed, early childhood is ready to learn many things including science. Great curiosity in children can be potentially exploited to introduce various concepts of science through exploration, observation and experimentation in the context of play. Children love to explore the surroundings with their senses, investigate objects and make experiments in their daily activities, including playing. Science is a science based on findings through investigations and experiments. So it is possible to introduce science to children through project activities.
The ability of the children's language possible to developed through the project-based science as project activities incorporate various abilities of children in their learning process, including language. Investigation activities develop the child's ability to present ideas, make inquiries, make notes and propose arguments. Exploration activities develop the child's ability to discover new concepts, new words and new meanings.

\section{References}

[1] Trends in International Mathematics and Science Study. 2011. http://nces.ed.gov/ pubsearch/pubsinfo.asp?pubid =2013009rev. acces on April 242016

[2] Lampiran 1 Permendikbud No. 137 Tahun 2014, Standar Nasional Pendidikan Anak Usia Dini

[3] Yilmaztekin, Aelif Öztürk \& Bfeyza Tantekin Erden. Early Childhood Teachers' Views About Science Teaching Practices. "Western Anatolia Journal of Educational Sciences (WAJES)".Dokuz Eylul University Institute, Izmir, Turkey. 2011: 161-168

[4] Helm, Judy Harris \& Lilian Katz,. Young Investigators; The Project Approach in The Early Years.. Teachers College Press, Columbia University. 2011

[5] Brooks, Margaret \& Tshering Wangmo, Introducing the Project Approach and Use of Visual Representation to Early Childhood Education in Bhutan, "Early Childhood Research \& Practice", Volume 13 Number 1, 2011

[6] Yeni Rachmawati dan Euis Kurniati. Strategi Pengembangan Kreativitas Anak Usia Taman Kanak-Kanak, (Jakarta: Kencana Prenada Media Group, 2010)

[7] Seefeldt, Carol \& Barbara A. Wasik.. Pendidikan Anak Usia Dini; Menyiapkan Anak Usia Tiga, Empat, dan Lima Tahun Masuk Sekolah, Jakarta: PT Indeks. 2008

[8] Jalongo. Mary Renck. Early Childhood Language Arts, Fourth Edition. Pearson Education. 2007 